\title{
MANFAAT DAN RISIKO YANG MEMPENGARUHI KELANJUTAN NIAT PENGGUNAAN FINTECH PEMBAYARAN SELULER
}

\author{
Afrida Putritama \\ Program Studi Akuntansi Fakultas Ekonomi Universitas Negeri Yogyakarta \\ aputritama@uny.ac.id
}

\begin{abstract}
Abstrak: Manfaat dan risiko yang mempengaruhi kelanjutan niat penggunaan Fintech pembayaran seluler. Tujuan penelitian ini adalah menemukan bagaimana manfaat persepsian dan risiko persepsian mempengaruhi kelanjutan niat penggunaan Fintech pembayaran seluler dengan mendasarkan kepada Theory of Reasoned Action (TRA). Pengumpulan data penelitian ini menggunakan kuesioner dengan metode purposive sampling dengan jumlah sampel sebanyak 104 responden. Pengujian hipotesis menggunakan Structural Equation Model (SEM) dengan alat ukur Partial Least Square (PLS). Penelitian ini menemukan bahwa manfaat persepsian lebih kuat dibandingkan risiko persepsian dalam mempengaruhi kelanjutan niat penggunaan Fintech pembayaran seluler. Faktor terkuat yang mempengaruhi manfaat persepsian adalah kenyamanan. Transaksi seamless dan manfaat ekonomi memiliki pengaruh positif namun tidak signifikan terhadap manfaat persepsian. Faktor terkuat yang mempengaruhi risiko persepsian adalah risiko keuangan. Faktor terkuat kedua yang mempengaruhi risiko persepsian adalah risiko hukum. Risiko keamanan dan risiko operasional memiliki pengaruh positif tidak signifikan terhadap risiko persepsian.
\end{abstract}

Kata kunci: Fintech pembayaran seluler, manfaat persepsian, risiko persepsian

Abstract: Benefits and risks that affect the continued use of mobile payments Fintech. The purpose of this research is to find out how the perceived benefit and perceived risks affect the continuation of the intention to use Fintech mobile payments based on the Theory of Reasoned Action (TRA). Research data collection using a questionnaire with a purposive sampling method with a total sample of 104 respondents. Hypothesis testing uses the Structural Equation Model (SEM) with the Partial Least Square (PLS) measuring instrument. This study found that the perceived benefit is stronger than the perceived risk in influencing the continuation of the intention to use mobile payment Fintech. The strongest factor affecting the perceived benefit is convenience. Seamless transactions and economic benefits have a positive but insignificant effect on perceived benefits. The strongest factor affecting perceived risk is financial risk. The second strongest factor affecting perceived risk is legal risk. Security risk and operational risk have an insignificant positive effect on perceived risk.

Keywords: Fintech mobile payments, perceived benefits, perceived risks

\section{PENDAHULUAN}

Penelitian ini dilatarbelakangi oleh maraknya pemanfaatan Fintech pembayaran seluler di Indonesia yang memberikan manfaat kemudahan, dan kenyamanan pembayaran bagi penggunanya seiring tingginya tingkat kepemilikan telepon seluler (De Luna et al, 2018). Fintech telah berhasil mengalahkan bank sebagai penyedia pembayaran utama di Indonesia dengan kepemilikan sebesar $36 \%$ nilai beredar dana di rekening e-money pada akhir 2018, dan meningkat menjadi 54\% pada akhir tahun 2019 menurut data Bank Indonesia (https://www.spglobal.com/marketintelligen ce/en/news-insights/research/southeast-asiae-money-market-report-shows-tech-firmsdisrupting-banks). Fintech dipandang sebagai teknologi yang mampu merevolusi peran industri perbankan, bahkan menjadi 


\section{Nominal: Barometer Riset Akuntansi dan Manajemen}

P-ISSN: 2303-2065 E-ISSN: 2502-5430

Volume 10 No 2 (2021)

salah satu terobosan teknologi yang berpotensi meningkatkan pemberdayaan ekonomi secara efektif (Wonglimpiyarat, 2017). Telah banyak diskusi di kalangan peneliti dan praktisi bisnis yang menyoroti pentingnya mempelajari perkembangan pembayaran seluler mengingat maraknya penggunaan beragam layanan pembayaran seluler di seluruh dunia sejak 2 dekade lampau (Iman, 2018). Penelitian yang membahas mengenai kelanjutan niat penggunaan layanan teknologi masih sangat terbatas (Keong, Leong, \& Bao, 2020) sehingga peneliti menganggap perlu meneliti lebih lanjut mengenai fenomena Fintech pembayaran seluler. Oleh karena itu peneliti menetapkan tujuan penelitian ini adalah menemukan bagaimana manfaat persepsian dan risiko persepsian mempengaruhi kelanjutan niat penggunaan Fintech pembayaran seluler.

\section{KAJIAN LITERATUR}

Fintech memiliki potensi manfaat besar bagi konsumen di seluruh dunia yang belum terlayani oleh lembaga keuangan konvensional (Jagtiani \& John, 2018). Fintech adalah sebuah solusi baru yang memanfaatkan pengembangan inovasi disruptif dari aplikasi, proses, produk, atau model bisnis dalam industri jasa keuangan (Alt \& Puschmann, 2012), sehingga ruang lingkupnya sangat luas namun pembahasan dalam penelitian ini dibatasi pada Fintech pembayaran seluler saja.

Penelitian mengenai Fintech pembayaran seluler ini mendasarkan pada Theory of Reasoned Action (TRA) dan terinspirasi oleh penelitian sebelumnya (Ryu, 2018) sehingga disusunlah paradigma penelitian seperti terlihat pada gambar 1 di bawah ini:

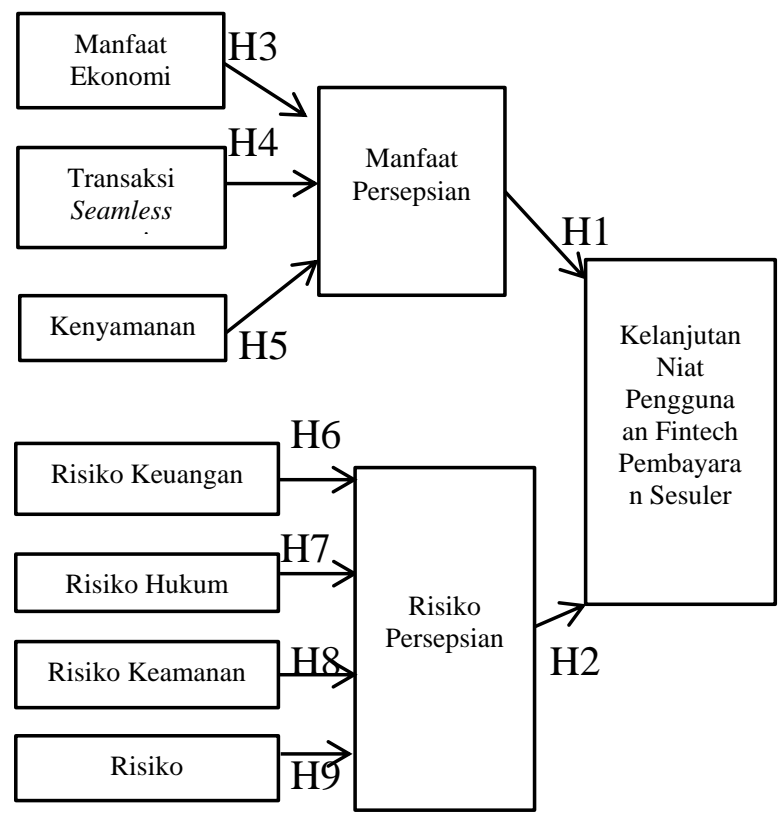

Gambar 1: Paradigma Penelitian

Salah satu faktor yang mempengaruhi kelanjutan niat penggunaan layanan teknologi adalah manfaat persepsian (Oghuma, Libaque-saenz, Wong, \& Chang, 2016). Manfaat persepsian mempengaruhi secara positif niat penggunaan layanan teknologi informasi (Ryu, 2018). Konsumen akan menggunakan suatu pembayaran seluler hanya jika konsumen yakin bahwa dengan menggunakan sistem tersebut akan membantu menghemat uang atau 


\section{Nominal: Barometer Riset Akuntansi dan Manajemen}

P-ISSN: 2303-2065 E-ISSN: 2502-5430

Volume 10 No 2 (2021)

meningkatkan efisiensi beragam transaksi mereka (Lwoga \& Lwoga, 2017).

Fintech pembayaran seluler tidak hanya menawarkan manfaat namun juga membawa risiko bagi pengguna. Penelitian terdahulu di bidang layanan teknologi pada umumnya menemukan bahwa risiko persepsian mempengaruhi secara negatif niat penggunaan layanan teknologi informasi. Risiko persepsian adalah risiko persepsian adalah tingkat dimana pengguna percaya akan keamanan suatu layanan teknologi (Elhajjar \& Ouaida, 2020). Persepsi pengguna terhadap perlindungan keamanan merupakan sebuah proses kognitif yang akan mempengaruhi emosi pengguna sekaligus kelanjutan niat penggunaan suatu layanan teknologi (Elhajjar \& Ouaida, 2020). Penelitian sebelumnya menemukan bahwa tiga dari empat dimensi risiko persepsian yaitu risiko keuangan, risiko hukum, dan risiko operasional memiliki pengaruh negatif signifikan terhadap niat penggunaan Fintech sedangkan 1 dimensi risiko persepsian lainnya yaitu risiko keamanan terbukti tidak memiliki pengaruh negatif yang signifikan terhadap niat penggunaan Fintech (Keong, Leong, \& Bao, 2020). Dalam konteks Fintech pembayaran seluler, risiko persepsian dapat diartikan sebagai persepsi negatif konsumen bahwa penyedia jasa Fintech pembayaran seluler tidak akan memenuhi persyaratan keamanan sehingga dimungkinkan pengguna mengalami kerugian saat melakukan transaksi. Jumlah kasus cybercrime yang semakin meningkat dari hari ke hari di seluruh dunia akan semakin meningkatkan risiko persepsian pengguna Fintech pembayaran seluler. Berdasarkan uraian di atas maka disusunlah hipotesis pertama dan kedua sebagai berikut:

H1. Manfaat persepsian berpengaruh positif terhadap kelanjutan niat penggunaan Fintech pembayaran seluler

H2. Risiko persepsian berpengaruh negatif terhadap kelanjutan niat penggunaan Fintech pembayaran seluler

Secara umum terdapat 3 faktor pendorong niat penggunaan Fintech pembayaran seluler yaitu manfaat ekonomi, kenyamanan, dan transaksi seamless. Faktor pendorong niat penggunaan Fintech yang pertama adalah manfaat ekonomi, antara lain berupa biaya transaksi yang lebih murah dan persyaratan yang lebih sederhana dibandingkan layanan jasa keuangan konvensional seperti bank. Perkembangan data analitik, pemanfaatan big data and peningkatan penggunaan telepon pintar di negara-negara berkembang mampu menciptakan kesempatan yang sama bagi setiap individu di seluruh dunia untuk menjangkau layanan keuangan yang disediakan perusahaan Fintech (Jagtiani \& John, 2018). Faktor pendorong penggunaan 


\section{Nominal: Barometer Riset Akuntansi dan Manajemen \\ P-ISSN: 2303-2065 E-ISSN: 2502-5430 \\ Volume 10 No 2 (2021)}

Fintech yang kedua yaitu kenyamanan. Kenyamanan menjadi unsur terpenting kesuksesan layanan seluler dan layanan online karena adanya tuntutan fleksibitas pengguna masa kini (Kim, Mirusmonov, \& Lee, 2009), (Ryu, 2018). Fintech pembayaran seluler memungkinkan pengguna menggunakan layanan pembayaran independen yang dapat dikustomisasi sesuai dengan kebutuhan masing-masing pengguna sehingga dapat mengoptimalkan kenyamanan pengguna (Kang, 2018). Faktor pendorong yang terakhir adalah transaksi seamless. Transaksi seamless secara sederhana dapat diartikan sebagai transaksi tanpa terlihat wujud fisik uang yang digunakan dalam transaksi tersebut karena memanfaatkan media lain yang mewakili fisik dari uang tersebut (Ryu, 2018). Ketiga faktor pendorong tersebut mempengaruhi manfaat persepsian Fintech pembayaran seluler sehingga disusunlah hipotesis sebagai berikut:

H3. Manfaat ekonomi berpengaruh secara positif terhadap manfaat persepsian

H4. Transaksi seamless berpengaruh secara positif terhadap manfaat persepsian

H5. Kenyamanan berpengaruh secara positif terhadap manfaat persepsian

Selain dipengaruhi oleh ketiga faktor pendorong di atas, niat penggunaan Fintech pembayaran seluler juga dipengaruhi oleh 4 faktor risiko yaitu risiko keamanan, risiko keuangan, risiko hukum, dan risiko operasional. Salah satu risiko yang menjadi perhatian utama pengguna Fintech dan regulator Fintech yaitu risiko keuangan, yang diartikan sebagai potensi pengeluaran moneter yang terkait dengan harga pembelian awal dan biaya perawatan berkelanjutan dari suatu produk (Featherman \& Pavlou, 2003). Pengguna dapat membuat kesalahan atau kekeliruan saat melakukan transaksi keuangan, seringkali pada saat membayar pihak ketiga, pemasok, atau toko yang mana kerugian tersebut tidak dapat dikembalikan kepada pengguna, jikalaupun dapat dikembalikan ke akun pengguna pada umumnya membutuhkan waktu cukup lama (Pal, Herath, De, \& Rao, 2020).

Risiko berikutnya yang tidak kalah penting adalah risiko hukum, yang didefinisikan sebagai risiko yang timbul akibat belum adanya peraturan hukum yang jelas mengenai Fintech pembayaran seluler (Ryu, 2018). Beragam regulasi Fintech dalam interaksinya dengan regulasi keuangan lain yang telah ada sebelumnya berpotensi memicu timbulnya risiko hukum (Jagtiani \& John, 2018).

Risiko berikutnya yang sering menjadi perhatian pengguna adalah risiko keamanan. Risiko keamanan yaitu risiko penyalahgunaan data personal pengguna oleh pihak yang tidak bertanggungjawab (Jagtiani 
\& John, 2018). Risiko yang terakhir adalah risiko operasional, yaitu potensi kerugian akibat kurangnya keterampilan operasional dan respon cepat karyawan, malfungsi sistem, and kurang layaknya proses internal perusahaan (Barakat \& Hussainey, 2013). Berdasarkan uraian di atas maka disusunlah hipotesis sebagai berikut:

H6. Risiko keuangan berpengaruh positif terhadap risiko persepsian

H7. Risiko hukum berpengaruh positif terhadap risiko persepsian

H8. Risiko keamanan berpengaruh positif terhadap risiko persepsian

H9. Risiko operasional berpengaruh secara positif terhadap risiko persepsian

\section{METODE PENELITIAN}

Pengumpulan data penelitian ini menggunakan kuesioner dengan metode purposive sampling. Populasi penelitian ini adalah pengguna Fintech pembayaran seluler di Daerah Istimewa Yogyakarta. Kuesioner yang berhasil dikumpulkan sebanyak 113 namun hanya 104 kuesioner yang memenuhi kriteria berupa responden pernah menjadi pengguna Fintech pembayaran seluler. Responden yang menggunakan Fintech pembayaran seluler kurang dari 6 bulan sebanyak 43 orang (41,3 persen), responden yang menggunakan Fintech pembayaran seluler antara 7 bulan hingga 1 tahun sebanyak 21 orang (20,2 persen) telah, dan responden yang telah menggunakan Fintech pembayaran seluler lebih dari 1 tahun sebanyak 40 orang $(38,5 \%)$ seperti yang tertera dalam tabel 1 di bawah ini.

Tabel 1: Karakteristik Responden

\begin{tabular}{ll}
\hline Karakteristik & Jumlah Kuesioner \\
\hline Periode penggunaan: & \\
$<6$ bulan & 43 \\
7 bulan - 1 tahun & 21 \\
$>1$ tahun & 40 \\
Usia: & \\
16 - 25 tahun & 101 \\
$26-35$ tahun & 1 \\
36-45 tahun & 1 \\
$56-65$ tahun & 1 \\
Jenis Kelamin: & \\
Laki-laki & 35 \\
Perempuan & 69 \\
Pendidikan: & \\
SMA & 93 \\
Sarjana & 9 \\
Pasca Sarjana & 2 \\
Frekuensi Penggunaan: & \\
Harian & 6 \\
Mingguan & 25 \\
Bulanan & 36 \\
Setiap 3 bulan & 17 \\
Setiap 6 bulan & 11 \\
Sekali setahun atau kurang dari itu & 9 \\
\hline
\end{tabular}

Tabel 2: Instrumen Penelitian

\begin{tabular}{|c|c|}
\hline Variabel & $\begin{array}{l}\text { Pernyataan } \\
\text { Kuesioner }\end{array}$ \\
\hline \multirow[t]{4}{*}{$\begin{array}{l}\text { Manfaat } \\
\text { Persepsian } \\
\text { (Perceived } \\
\text { Benefit) }\end{array}$} & $\begin{array}{lr}\text { Menggunakan } & \text { Fintech } \\
\text { pembayaran } & \text { seluler } \\
\text { memberikan } & \text { banyak } \\
\text { keuntungan bagi sava } & \end{array}$ \\
\hline & $\begin{array}{l}\text { Saya dapat dengan mudah dan } \\
\text { cepat menggunakan Fintech } \\
\text { pembayaran seluler }\end{array}$ \\
\hline & $\begin{array}{lr}\text { Menggunakan } & \text { Fintech } \\
\text { pembayaran } & \text { seluler } \\
\text { bermanfaat bagi saya } & \end{array}$ \\
\hline & $\begin{array}{l}\text { Menggunakan } \\
\text { pembayaran } \\
\text { menghasilkan kualitas hasil } \\
\text { yang lebih unggul daripada } \\
\text { layanan keuangan tradisional }\end{array}$ \\
\hline
\end{tabular}




\begin{tabular}{|c|c|}
\hline Variabel & $\begin{array}{ll}\text { Pernyataan } & \text { Dalam } \\
\text { Kuesioner } & \\
\end{array}$ \\
\hline \multirow[t]{3}{*}{$\begin{array}{l}\text { Risiko } \\
\text { Persepsian } \\
\text { (Perceived } \\
\text { Risk) }\end{array}$} & $\begin{array}{l}\text { Menggunakan } \\
\text { pembayaran } \\
\text { memberikan risiko tinggi bagi } \\
\text { saya }\end{array}$ \\
\hline & $\begin{array}{l}\text { Ada tingkat ketidakpastian } \\
\text { yang tinggi saat saya } \\
\text { menggunakan } \\
\text { pembayaran seluler }\end{array}$ \\
\hline & $\begin{array}{l}\text { Menurut saya secara umum } \\
\text { menggunakan Fintech } \\
\text { pembayaran seluler hanya } \\
\text { memberikan sedikit manfaat } \\
\text { apabila dibandingkan dengan } \\
\text { layanan keuangan tradisional }\end{array}$ \\
\hline \multirow[t]{3}{*}{$\begin{array}{l}\text { Manfaat } \\
\text { Ekonomi } \\
\text { (Economic } \\
\text { benefit) }\end{array}$} & $\begin{array}{l}\text { Menggunakan } \\
\text { pembayaran seluler lebih } \\
\text { murah dibandingkan } \\
\text { menggunakan } \\
\text { keuangan tradisional }\end{array}$ \\
\hline & $\begin{array}{l}\text { Saya bisa menghemat uang } \\
\text { dengan menggunakan Fintech } \\
\text { pembayaran seluler }\end{array}$ \\
\hline & $\begin{array}{l}\text { Saya dapat menggunakan } \\
\text { berbagai layanan keuangan } \\
\text { dengan biaya rendah jika saya } \\
\text { menggunakan Fintech } \\
\text { pembayaran seluler }\end{array}$ \\
\hline \multirow[t]{3}{*}{$\begin{array}{l}\text { Transaksi } \\
\text { Seamless } \\
\text { (Seamless } \\
\text { Transaction) }\end{array}$} & $\begin{array}{lr}\text { Saya dapat mengontrol } \\
\text { penggunaan uang saya tanpa } \\
\text { perantara ketika saya } \\
\text { menggunakan } \\
\text { pembayaran seluler }\end{array}$ \\
\hline & $\begin{array}{l}\text { Saya dapat menggunakan } \\
\text { berbagai layanan keuangan } \\
\text { pada saat yang bersamaan } \\
\text { ketika saya menggunakan } \\
\text { Fintech pembayaran seluler }\end{array}$ \\
\hline & $\begin{array}{l}\text { Saya dapat melakukan } \\
\text { transaksi peer-to-peer antara } \\
\text { penyedia dan pengguna tanpa } \\
\text { perantara ketika saya } \\
\text { menggunakan } \\
\text { pembayaran seluler }\end{array}$ \\
\hline $\begin{array}{l}\text { Kenyamanan } \\
\text { (Convenience) }\end{array}$ & $\begin{array}{lr}\text { Saya dapat menggunakan } \\
\text { layanan keuangan } \\
\text { sangat cepat } & \text { ketika } \\
\text { menggunakan } & \text { Fintech } \\
\text { pembayaran seluler } & \end{array}$ \\
\hline
\end{tabular}

\begin{tabular}{|c|c|}
\hline Variabel & $\begin{array}{l}\text { Pernyataan } \\
\text { Kuesioner }\end{array}$ \\
\hline & $\begin{array}{l}\text { Saya dapat menggunakan } \\
\text { layanan jasa keuangan } \\
\text { kapanpun dan dimanapun } \\
\text { ketika menggunakan Fintech } \\
\text { pembayaran seluler }\end{array}$ \\
\hline & $\begin{array}{l}\text { Saya dapat menggunakan } \\
\text { layanan keuangan dengan } \\
\text { mudah ketika menggunakan } \\
\text { Fintech pembayaran seluler }\end{array}$ \\
\hline \multirow[t]{3}{*}{$\begin{array}{l}\text { Risiko } \\
\text { Keuangan } \\
\text { (Financial } \\
\text { Risk) }\end{array}$} & $\begin{array}{l}\text { Kerugian finansial sangat } \\
\text { mungkin terjadi ketika saya } \\
\text { menggunakan Fintech } \\
\text { pembayaran seluler }\end{array}$ \\
\hline & $\begin{array}{lr}\text { Financial fraud atau fraud } \\
\text { pembayaran sangat mungkin } \\
\text { terjadi ketika } \\
\text { menggunakan saya } \\
\text { pembayaran seluler }\end{array}$ \\
\hline & $\begin{array}{l}\text { Kerugian finansial karena } \\
\text { kurangnya interoperabilitas } \\
\text { dengan layanan lain } \\
\text { kemungkinan besar terjadi } \\
\text { ketika saya menggunakan } \\
\text { Fintech pembayaran seluler }\end{array}$ \\
\hline \multirow[t]{3}{*}{$\begin{array}{l}\text { Risiko Hukum } \\
\text { (Legal Risk) }\end{array}$} & $\begin{array}{l}\text { Fintech pembayaran seluler } \\
\text { yang saya gunakan serba tidak } \\
\text { pasti dikarenakan ada } \\
\text { beragam regulasi } \\
\text { Tidak mudah menggunakan } \\
\text { Fintech pembayaran seluler } \\
\text { dengan adanya peraturan } \\
\text { pemerintah yang membatasi } \\
\text { penggunaannya }\end{array}$ \\
\hline & $\begin{array}{lcc}\text { Ada } & \text { ketidakpastian } & \text { hukum } \\
\text { bagi } & \text { pengguna } & \text { Fintech } \\
\text { pembayaran seluler } & \\
\end{array}$ \\
\hline & $\begin{array}{l}\text { Aplikasi Fintech pembayaran } \\
\text { seluler sulit digunakan karena } \\
\text { regulasi pemerintah yang } \\
\text { membatasinya }\end{array}$ \\
\hline \multirow[t]{2}{*}{$\begin{array}{l}\text { Risiko } \\
\text { Keamanan } \\
\text { (Security Risk) }\end{array}$} & $\begin{array}{lr}\text { Saya khawatir } & \text { tentang } \\
\text { penyalahgunaan informasi } & \text { in } \\
\text { keuangan saya ketika saya } \\
\text { menggunakan } \\
\text { pembayaran seluler }\end{array}$ \\
\hline & $\begin{array}{l}\text { Informasi keuangan saya } \\
\text { tidak aman ketika saya } \\
\text { menggunakan } \\
\text { pembayaran seluler }\end{array}$ \\
\hline
\end{tabular}




\begin{tabular}{|c|c|}
\hline Variabel & $\begin{array}{ll}\text { Pernyataan } & \text { Dalam } \\
\text { Kuesioner } & \\
\end{array}$ \\
\hline \multirow{5}{*}{$\begin{array}{l}\text { Risiko } \\
\text { Operasional } \\
\text { (Operational } \\
\text { Risk) }\end{array}$} & $\begin{array}{lcc}\text { Saya } & \text { khawatir } & \text { seseorang } \\
\text { dapat mengakses } & \text { informasi } \\
\text { keuangan saya ketika saya } \\
\text { menggunakan } & \text { Fintech } \\
\text { pembayaran seluler } & \end{array}$ \\
\hline & \begin{tabular}{llr} 
Perusahaan & \multicolumn{2}{r}{ Fintech } \\
pembayaran & seluler tidak \\
bersedia & menyelesaikan
\end{tabular} \\
\hline & $\begin{array}{llr}\text { masalah } & \text { ketika } & \text { terjadi } \\
\text { kerugian } & \text { finansial } & \text { atau } \\
\text { kebocoran } & & \text { informasi } \\
\text { keuangan } & & \end{array}$ \\
\hline & $\begin{array}{l}\text { Tanggapan } \\
\text { Fintech perusahaan } \\
\text { ketika terjadi kerugian } \\
\text { finansial atau kebocoran } \\
\text { informasi keuangan sangat } \\
\text { lambat }\end{array}$ \\
\hline & $\begin{array}{l}\text { Saya khawatir mengenai } \\
\text { tanggapan perusahaan Fintech } \\
\text { pembayaran seluler ketika } \\
\text { terjadi kerugian keuangan } \\
\text { atau kebocoran informasi } \\
\text { keuangan }\end{array}$ \\
\hline \multirow[t]{3}{*}{$\begin{array}{l}\text { Kelanjutan } \\
\text { Niat } \\
\text { Penggunaan } \\
\text { (Continuance } \\
\text { Intention) }\end{array}$} & $\begin{array}{l}\text { Saya secara positif yakin } \\
\text { mempertimbangkan Fintech } \\
\text { pembayaran seluler dalam } \\
\text { rangkaian pilihan saya }\end{array}$ \\
\hline & $\begin{array}{l}\text { Saya lebih memilih Fintech } \\
\text { pembayaran seluler } \\
\text { Saya berniat untuk terus } \\
\text { menggunakan Fintech } \\
\text { pembayaran seluler }\end{array}$ \\
\hline & $\begin{array}{l}\text { Saya akan menggunakan } \\
\text { Fintech di masa mendatang }\end{array}$ \\
\hline
\end{tabular}

Sumber: Ryu, 2018

\section{HASIL PENELITIAN DAN \\ PEMBAHASAN}

Indikator konstruk dikatakan valid jika memiliki nilai korelasi di atas 0.70 namun pada penelitian tahap awal pengembangan skala, nilai loading 0.60 sampai 0.70 masih dianggap cukup atau diterima. Nilai composite reliability dan cronbach alpha pada tabel 3 menunjukkan bahwa konstruk memenuhi persyaratan uji reliabilitas dan dinyatakan reliabel. Data tabel 3 juga menunjukkan nilai cross loading yang memenuhi syarat sehingga secara keseluruhan dapat disimpulkan bahwa konstruk memiliki validitas konvergen dan validitas diskriminan yang baik.

Tabel 3: Hasil Pengukuran Reliabilitas dan Validitas

\begin{tabular}{lccc}
\hline Item & Cronbach $\boldsymbol{\alpha C o m p . ~ R e l i a b i l i t y ~}$ & Loading \\
\hline PB1 & O,873 & 0,915 & 0,888 \\
PB2 & O,873 & 0,915 & 0,883 \\
PB3 & O,873 & 0,915 & 0,918 \\
PB4 & O,873 & 0,915 & 0,715 \\
PR1 & O,623 & 0,831 & 0,749 \\
PR2 & O,623 & 0,831 & 0,930 \\
EB1 & 0,707 & 0,822 & 0,839 \\
EB2 & 0,707 & 0,822 & 0,614 \\
EB3 & 0,707 & 0,822 & 0,867 \\
ST1 & 0,735 & 0,849 & 0,748 \\
ST2 & 0,735 & 0,849 & 0,841 \\
ST3 & 0,735 & 0,849 & 0,832 \\
C1 & 0,753 & 0,858 & 0,810 \\
C2 & 0,753 & 0,858 & 0,884 \\
C3 & 0,753 & 0,858 & 0,755 \\
FR1 & 0,677 & 0,358 & 0,906 \\
FR2 & 0,677 & 0,358 & 0,718 \\
FR3 & 0,677 & 0,358 & 0,646 \\
LR1 & 0,642 & 0,805 & 0,755 \\
LR2 & 0,642 & 0,805 & 0,723 \\
LR4 & 0,642 & 0,805 & 0,805 \\
SR2 & 0,610 & 0,667 & 0,955 \\
SR3 & 0,610 & 0,667 & 0,405 \\
OR1 & 0,715 & 0,786 & 0,941 \\
OR2 & 0,715 & 0,786 & 0,604 \\
OR3 & 0,715 & 0,786 & 0,657 \\
CI1 & 0,820 & 0,883 & 0,717 \\
CI2 & 0,820 & 0,883 & 0,722 \\
CI3 & 0,820 & 0,883 & 0,918 \\
CI4 & 0,820 & 0,883 & 0,866 \\
\hline & & & \\
& &
\end{tabular}

Analisis menggunakan PLS dilakukan dengan melihat nilai $R$-square yang merupakan uji goodness-fit model, selanjutnya adalah melihat signifikansi 


\section{Nominal: Barometer Riset Akuntansi dan Manajemen \\ P-ISSN: 2303-2065 E-ISSN: 2502-5430 \\ Volume 10 No 2 (2021)}

pengaruh antar konstruk dengan melihat hasil path coefficients. Hasil pengujian goodnessfit model terlihat pada hasil nilai R-square dalam tabel 4 di bawah ini. Nilai $R$-square dari variabel continuous intention sebesar 0,357 menunjukkan bahwa variabel continuous intention dapat dijelaskan oleh variabel dalam model sebesar $35,7 \%$ dan sisanya $64,3 \%$ dijelaskan oleh variabel lain di luar model penelitian. Nilai $R$-square dari variabel perceived benefit sebesar 0,409 menunjukkan bahwa variabel perceived benefit dapat dijelaskan oleh variabel dalam model sebesar $40,9 \%$ dan sisanya $59,1 \%$ dijelaskan oleh variabel lain di luar model penelitian. Berikutnya nilai $R$-square dari variabel perceived risk sebesar 0,265 menunjukkan bahwa variabel perceived risk dapat dijelaskan oleh variabel dalam model sebesar $26,5 \%$ dan sisanya $73,5 \%$ dijelaskan oleh variabel lain di luar model penelitian.

Tabel 4: R-Square

\begin{tabular}{ll}
\hline Variabel & R-Square \\
\hline Continuous Intention & 0,357 \\
Perceived Benefit & 0,409 \\
Perceived Risk & 0,265 \\
\hline
\end{tabular}

Hasil pengujian hipotesis pada tabel 5 dapat diinterpretasikan dengan melihat nilai original sample untuk mengetahui hubungan antar variabel yang diteliti, sedangkan untuk mengetahui tingkat signifikansi pengaruh hubungan antar variabel dapat dilihat pada $p$ values yaitu apabila p-values < 0.05 maka hasilnya signifikan. Hasil path coefficients pada tabel 5 menunjukkan PB (perceived benefit) mempengaruhi secara positif CI (continuous intention) dengan nilai koefisien parameter 0.532 yang artinya memiliki pengaruh positif, dan p-values sebesar $0,000<0,05$ menunjukkan hasil yang signifikan. Berdasarkan hasil tersebut, terbukti bahwa manfaat persepsian memiliki pengaruh positif signifikan terhadap niat penggunaan Fintech pembayaran seluler sehingga hipotesis 1 terdukung. Hasil ini memiliki arti bahwa semakin tinggi persepsi manfaat dari layanan Fintech pembayaran seluler maka semakin tinggi pula kelanjutan niat penggunaan Fintech pembayaran seluler. Hal ini konsisten dengan penelitian sebelumnya (Oghuma, Libaque-saenz,Wong \& Chang, 2016), (Ryu, 2018), dan (Diana \& Leon, 2020).

Hasil path coefficients pada tabel 5 menunjukkan $\mathrm{PR}$ (perceived risk) mempengaruhi secara positif CI (continuous intention) dengan nilai koefisien parameter 0,195 yang artinya memiliki pengaruh positif, dan $p$-values sebesar 0,031<0,05 menunjukkan hasil yang signifikan. Berdasarkan hasil tersebut, terbukti bahwa risiko persepsian memiliki pengaruh positif signifikan terhadap kelanjutan niat penggunaanFintech pembayaran seluler sehingga hipotesis 2 tidak terdukung. Hal ini mungkin dikarenakan mayoritas responden percaya bahwa sistem pengendalian internal 


\section{Nominal: Barometer Riset Akuntansi dan Manajemen \\ P-ISSN: 2303-2065 E-ISSN: 2502-5430 \\ Volume 10 No 2 (2021)}

perusahaan Fintech pembayaran seluler sudah memadai dan telah memenuhi regulasi pemerintah, sehingga risiko persepsian tidak menghalangi kelanjutan niat penggunaan Fintech pembayaran seluler. Temuan ini konsisten dengan penelitian sebelumnya (Sai, Zailani, Iranmanesh, \& Sean, 2017) namun bertentangan dengan beberapa temuan penelitian lain (Ryu, 2018), (Lee \& Kim, 2020), (Elhajjar \& Ouaida, 2020), dan (Diana \& Leon, 2020).

Nilai $p$-values menunjukkan manfaat persepsian lebih kuat dibandingkan risiko persepsian. Artinya dalam perspektif pengguna, potensi manfaat Fintech pembayaran seluler dianggap lebih besar dibandingkan potensi risiko Fintech pembayaran seluler sehingga adanya risiko persepsian tidak menghalangi niat pengguna untuk menggunakan Fintech pembayaran seluler.

Hasil path coefficients pada tabel 5 menunjukkan EB (Economic Benefit) mempengaruhi secara positif $\mathrm{PB}$ (perceived benefit) dengan nilai koefisien parameter 0,093 yang artinya memiliki pengaruh positif, dan p-values sebesar 0,330>0,05 menunjukkan hasil tidak signifikan. Berdasarkan hasil tersebut, terbukti bahwa manfaat ekonomi memiliki pengaruh positif tidak signifikan terhadap manfaat persepsian sehingga hipotesis 3 terdukung. Manfaat ekonomi memiliki pengaruh positif terhadap manfaat persepsian artinya semakin tinggi manfaat ekonomi maka semakin tinggi pula manfaat yang dipersepsikan oleh pengguna sehingga pada akhirnya semakin tinggi pula kelanjutan niat penggunaan Fintech pembayaran seluler. Hal ini konsisten dengan penelitian sebelumnya (Ryu, 2018), dan (Diana \& Leon, 2020).

Hasil path coefficients pada tabel 5 menunjukkan ST (seamless transaction) mempengaruhi secara positif PB (perceived benefit) dengan nilai koefisien parameter 0,145 yang artinya memiliki pengaruh positif, dan nilai p-values sebesar 0,152>0,05 menunjukkan hasil tidak signifikan. Berdasarkan hasil tersebut, terbukti bahwa transaksi seamless memiliki pengaruh positif tidak signifikan terhadap manfaat persepsian sehingga hipotesis 4 terdukung. Transaksi seamless memiliki pengaruh positif terhadap manfaat persepsian artinya transaksi seamless mempengaruhi proses pengambilan keputusan kelanjutan niat penggunaan Fintech pembayaran seluler di masa depan. Hasil ini konsisten dengan penelitian sebelumnya (Zavolokina, Dolata, \& Schwabe, 2016), (Ryu, 2018), dan (Diana $\&$ Leon, 2020).

Hasil path coefficients pada tabel 5 menunjukkan $\mathrm{C}$ (convenience) mempengaruhi secara positif $\mathrm{PB}$ (perceived benefit) dengan nilai koefisien parameter 0,494 yang artinya memiliki pengaruh 


\section{Nominal: Barometer Riset Akuntansi dan Manajemen \\ P-ISSN: 2303-2065 E-ISSN: 2502-5430 \\ Volume 10 No 2 (2021)}

positif, dan $p$-values sebesar $0,000<0,05$ menunjukkan hasil signifikan. Berdasarkan hasil tersebut, terbukti bahwa kenyamanan memiliki pengaruh positif signifikan terhadap manfaat persepsian sehingga hipotesis 5 terdukung. Hasil ini mengindikasikan bahwa semakin tinggi kenyamanan yang dirasakan oleh pengguna saat melakukan transaksi maka akan semakin tinggi pula persepsi manfaat pengguna sehingga pada akhirnya meningkatkan kelanjutan niat penggunaan Fintech pembayaran seluler. Hasil ini konsisten dengan penelitian sebelumnya (Kim, Mirusmonov, \& Lee, 2009), (Ryu, 2018), dan (Diana \& Leon, 2020).

Tabel 5: Hasil Path Coefficients

\begin{tabular}{lccc}
\hline $\begin{array}{c}\text { Org. } \\
\text { Sample }\end{array}$ & $\mathbf{P}$ & Values & Keterangan \\
\hline PB -> CI & 0,532 & 0,000 & Diterima \\
PR -> CI & 0,195 & 0,031 & Tidak Diterima \\
EB -> PB & 0,093 & 0,330 & Diterima \\
ST -> PB & 0,145 & 0,152 & Diterima \\
C -> PB & 0,494 & 0,000 & Diterima \\
FR -> PR & 0,268 & 0,005 & Diterima \\
LR -> PR & 0,241 & 0,012 & Diterima \\
SR -> PR & 0,183 & 0,082 & Diterima \\
OR -> PR & 0,088 & 0,387 & Diterima \\
\hline
\end{tabular}

Hasil path coefficients pada tabel 5 menunjukkan FR (financial risk) mempengaruhi secara positif PR (perceived risk) dengan nilai koefisien parameter 0,268 yang artinya memiliki pengaruh positif, dan p-values sebesar 0,005<0,05 menunjukkan hasil signifikan. Berdasarkan hasil tersebut, terbukti bahwa risiko keuangan memiliki pengaruh positif signifikan terhadap risiko persepsian sehingga hipotesis 6 terdukung. Risiko keuangan memiliki pengaruh positif terhadap risiko persepsian artinya semakin tinggi risiko finansial yang dialami pengguna saat melakukan transaksi menggunakan Fintech pembayaran seluler makan akan semakin tinggi persepsi risiko pengguna sehingga pada akhirnya mempengaruhi keberlanjutan niat penggunaan Fintech pembayaran seluler. Hal ini konsisten dengan penelitian sebelumnya (Ariff et al, 2014), (Ryu, 2018), dan (Diana \& Leon, 2020).

Hasil path coefficients pada tabel 5 menunjukkan LR (legal risk) mempengaruhi secara positif PR (perceived risk) dengan nilai koefisien parameter 0,241 yang artinya memiliki pengaruh positif, dan $p$-values sebesar $0,012<0,05$ menunjukkan hasil signifikan. Berdasarkan hasil tersebut, terbukti bahwa risiko hukum memiliki pengaruh positif signifikan terhadap risiko persepsian sehingga hipotesis 7 terdukung. Risiko hukum memiliki pengaruh positif terhadap risiko persepsian artinya semakin tinggi resiko hukum yang dirasakan oleh pengguna saat melakukan transaksi pembayaran menggunakan Fintech pembayaran seluler maka semakin tinggi pula risiko yang dirasakan pengguna sehingga mempengaruhi kelanjutan niat penggunaan Fintech pembayaran seluler. Hal ini konsisten dengan penelitian sebelumnya 


\section{Nominal: Barometer Riset Akuntansi dan Manajemen \\ P-ISSN: 2303-2065 E-ISSN: 2502-5430 \\ Volume 10 No 2 (2021)}

(Jagtiani \& John, 2018), (Ryu, 2018), dan (Diana \& Leon, 2020).

Hasil path coefficients pada tabel 5 menunjukkan SR (security risk) mempengaruhi secara positif PR (perceived risk) dengan nilai koefisien parameter 0,183 yang artinya memiliki pengaruh positif, dan $p$-values sebesar 0,082>0,05 menunjukkan hasil tidak signifikan. Berdasarkan hasil tersebut, terbukti bahwa risiko keamanan memiliki pengaruh positif tidak signifikan terhadap risiko persepsian sehingga hipotesis 8 terdukung. Risiko keamanan memiliki pengaruh positif terhadap risiko persepsian artinya semakin tinggi risiko keamanan yang mungkin terjadi pada saat menggunakan Fintech pembayaran seluler maka semakin tinggi pula resiko persepsian. Hasil ini konsisten dengan penelitian sebelumnya (Olusolade, 2016), (Ryu, 2018), dan (Diana $\&$ Leon, 2020).

Hasil path coefficients pada tabel 5 menunjukkan OR (operational risk) mempengaruhi secara positif PR (perceived risk) dengan nilai koefisien parameter 0,088 yang artinya memiliki pengaruh positif, dan p-values sebesar 0,387>0,05 menunjukkan hasil tidak signifikan. Berdasarkan hasil tersebut, terbukti bahwa risiko operasional memiliki pengaruh positif tidak signifikan terhadap risiko persepsian sehingga hipotesis 9 terdukung. Risiko operasional memiliki pengaruh positif terhadap risiko persepsian artinya semakin tinggi risiko operasional yang mungkin terjadi pada saat menggunakan Fintech pembayaran seluler maka semakin tinggi pula resiko persepsian dalam perspektif pengguna Fintech pembayaran seluler, yang mana hasil ini konsisten dengan penelitian sebelumnya (Barakat \& Hussainey, 2013), dan (Ryu, 2018).

Berdasarkan uraian di atas, dapat disimpulkan bahwa penelitian ini menemukan bahwa semua hipotesis terdukung kecuali hipotesis kedua. Kenyamanan adalah faktor terkuat yang mempengaruhi manfaat persepsian. Meskipun demikian, transaksi seamless dan manfaat ekonomi juga memiliki pengaruh positif meskipun tidak signifikan terhadap manfaat persepsian. Hal ini mengindikasikan bahwa terkait manfaat persepsian, kelanjutan niat penggunaan Fintech pembayaran seluler tidak hanya ditentukan oleh kenyamanan semata namun juga oleh adanya transaksi seamless dan manfaat ekonomi yang diterima pengguna.

Risiko keuangan adalah faktor terkuat yang mempengaruhi risiko persepsian. Risiko hukum juga memiliki pengaruh positif signifikan terhadap risiko persepsian sedangkan risiko keamanan dan risiko operasional memiliki pengaruh positif tidak signifikan terhadap risiko persepsian. Hal ini mengindikasikan bahwa terkait risiko 
persepsian, kelanjutan niat penggunaan Fintech pembayaran seluler tidak sematamata hanya ditentukan oleh risiko keuangan semata namun juga ditentukan oleh risiko hukum, risiko keamanan, dan risiko operasional.

\section{SIMPULAN DAN SARAN}

Simpulan penelitian ini adalah manfaat persepsian lebih kuat dibandingkan risiko persepsian dalam mempengaruhi kelanjutan niat penggunaan Fintech pembayaran seluler. Kenyamanan adalah faktor terkuat yang mempengaruhi manfaat persepsian, sedangkan risiko keuangan adalah faktor terkuat yang mempengaruhi risiko persepsian.

Keterbatasan penelitian ini adalah responden penelitian hanya berjumlah 104 orang di Daerah Istimewa Yogyakarta. Peneliti menyarankan penelitian selanjutnya menambah jumlah responden penelitian dari berbagai wilayah agar lebih mampu menggambarkan populasi pengguna Fintech pembayaran seluler yang sesungguhnya.

\section{DAFTAR PUSTAKA}

Alt, R., \& Puschmann, T. (2012). The Rise of Customer-Oriented Banking Electronic Markets are Paving the Way. Electronic Markets 22 (4), pp. 203-215. https://doi.org/10.1007/s12525-0120106-2

Ariff, Mohd Shoki Md, Sylvester, Michele,
Zakuan, Norhayati, Ismail, Khalid, Ali, Kamarudin Mat (2014). Consumer Perceived Risk, Attitude and Online Shopping Behaviour; Empirical Evidence from Malaysia. IOP Conf. Series: Materials Science and Engineering 58 https://doi.org/10.1088/1757899X/58/1/012007

Barakat, A., \& Hussainey, K. (2013). Bank governance, regulation, supervision, and risk reporting: Evidence from operational risk disclosures in European banks. International Review of Financial Analysis, 30, 254-273

De Luna, I.R., Liébana-cabanillas, F., Sánchez-fernández, J., \& Muñoz-leiva, F. (2018). Technological Forecasting \& Social Change Mobile payment is not all the same: The adoption of mobile payment systems depending on the technology applied. Technological Forecasting \& Social Change, (October 2017), 1-14. https://doi.org/10.1016/j.techfore.2018 .09 .018

Diana, N., \& Leon, F. M. (2020). Faktors Affecting Continuance Intention of FinTech Payment among Millennials in Jakarta. European Journal of Business and Management Research, 5(4), 1-9

Elhajjar, S. \& Ouaida, F. (2019). An analysis of faktors affecting mobile banking adoption. International Journal of Bank Marketing, Vol. 38 No. 2, pp. 352-367. https://doi.org/10.1108/IJBM-022019-0055

Featherman, M. S., \& Pavlou, P. A. (2003). Predicting e-services adoption : a perceived risk facets perspective. International Journal of HumanComputer Studies, 59, 451-474. https://doi.org/10.1016/S1071- 


\section{9(03)00111-3}

Iman, N. (2018). Is mobile payment still relevant in the fintech era? Electronic Commerce Research and Applications, (May). https://doi.org/10.1016/j.elerap.2018.0 5.009

Jagtiani, J. \& John, K. (2018). Fintech: The Impact on Consumers and Regulatory Responses. Journal of Economics and Business, 100, 1-6. https://doi.org/10.1016/j.jeconbus.201 8.11 .002

Kang, J. (2018). Mobile payment in Fintech environment: trends, security challenges, and services. HumanCentric Computing and Information Sciences, 8 https://doi.org/10.1186/s 13673-0180155-4

Keong, O. C., Leong, T. K., \& Bao, C.J. (2020). Perceived Risk Faktors Affect Intention To Use FinTech Perceived Risk Faktors Affect Intention to Use FinTech. Journal of Accounting and Finance in Emerging Economies, 6 (2), https://doi.org/10.26710/jafee.v6i2.11 01

Kim, C., Mirusmonov, M., \& Lee, I. (2009). An empirical examination of faktors influencing. Computers In Human Behavior, https://doi.org/10.1016/j.chb.2009.10. 013

Lee, J.M., \& Kim, H.J. (2020). Determinants of adoption and continuance intentions toward Internet-only banks. International Journal of Bank Marketing, 38 (4), 843-865 https://doi.org/10.1108/IJBM-072019-0269

Lwoga, E.T . \& Lwoga, N. B. (2017). User Acceptance of Mobile Payment: The
Effects of User-Centric Security, System Characteristics and Gender. The Electronic Journal of Information Systems in Developing Countries, 81 (3), 1-24. https://doi.org/10.1002/j.16814835.2017.tb00595.x

Nariyanuri, Sampath Sharma (2021). Southeast Asia E-Money Market Report Shows Tech Firms Disrupting Banks. https://www.spglobal.com/marketintelli gence/en/newsinsights/research/southeast-asia-emoney-market-report-shows-techfirms-disrupting-banks

Oghuma, A. P., Libaque-saenz, C. F., Wong, S. F., \& Chang, Y. (2020). Telematics and Informatics An expectationconfirmation model of continuance intention to use mobile instant messaging. Telematics and Informatics, 33 (1), 34-47. https://doi.org/10.1016/j.tele.2015.05. 006

Olusolade, Fadare (2016). A Survey on Perceived Risk and Intention of Adopting Internet Banking. Journal of Internet Banking and Commerce, 21(1), 1-21

Pal, A., Herath, T., De, R., \& Rao, H. R. (2020). Is the Convenience Worth the Risk? An Investigation of Mobile Payment Usage. Information Systems Frontiers. https://doi.org/10.1007/s10796-02010070-z

Ryu, H. (2018). What makes users willing or hesitant to use Fintech?: the moderating effect of user type. Industrial Management \& Data Systems, Vol. 118, No. 3, 541-569.

Sai, G., Zailani, S., Iranmanesh, M., \& Sean, 
Nominal: Barometer Riset Akuntansi dan Manajemen

P-ISSN: 2303-2065 E-ISSN: 2502-5430

Volume 10 No 2 (2021)

S. (2017). Mobile taxi booking application service' $\mathrm{s}$ continuance usage intention by users. Transportation Research Part D, 57(October), 207-216. https://doi.org/10.1016/j.trd.2017.07.0 23

Wonglimpiyarat, J. (2017). FinTech banking industry: a systemic approach. Foresight, Vol. 19 Issue: 6, pp.590603, https://doi.org/10.1108/FS-072017-0026

Zavolokina, L., Dolata, M., \& Schwabe, G. (2016). FinTech - What's in a Name?, Thirty Seventh International Conference on Information Systems 